\title{
Hvordan valideres tværsproglige kategorier? Aspekt som eksempel
}

\section{Kasper Boye, Jessie Leigh Nielsen \& Peter Harder}

\begin{abstract}
The precise status of cross-linguistic categories remains a contested issue in contemporary linguistics. This paper proposes a solution based on a functional rethinking of classic concepts in Danish structural linguistics. It is argued that the level of content substance constitutes the necessary starting point for typological categories (such as tense and aspect), distinct from but presupposed by structural categories. This theory is compared to Haspelmath's influential notion of "comparative concepts". Comparative concepts arise as subjective stipulations (as claimed by Haspelmath), but we argue that they can be evaluated and potentially validated as cross-linguistically real substance descriptions. A validation procedure based on semantic mapping is proposed and illustrated in an analysis of Comrie's (1976) category of aspect, which is argued - in contrast to what is generally assumed - not to constitute a cross-linguistically valid semantic domain. We conclude, however, that the category of aspect does constitute a different type of generalization: a generalization over cross-linguistically frequent distinctions.
\end{abstract}

\section{Nøgleord}

typologi, sprogspecifikke kategorier, komparative ka-tegorier, struktur, substans, semantiske kort, aspekt

\section{Indledning}

Denne artikel omhandler spørgsmålet om tværsproglige kategoriers status og deres forhold til sprogspecifikke kategorier. En afklaring af dette spørgsmål kan med fordel, og i overensstemmelse med dansk lingvistisk tradition, spaltes op til to underspørgsmål: 1) Spørgsmålet om forholdet mellem rent 
semantiske "substans"-kategorier, baseret udelukkende på indholdsmæssige sondringer, og strukturelle kategorier, baseret på kontraster der er systematisk indkodet. 2) Spørgsmålet om hvilken status tværsproglige kategorier har i forhold til sprogspecifikke kategorier (substansbaserede såvel som strukturelle). Artiklen opstiller og argumenterer for fire hypoteser om hvordan dette problemkompleks bedst kan behandles.

Tværsproglige kategorier har det grammatiske fundament at de opstilles når man konstaterer ligheder mellem sprog med hensyn til hvilke betydningsområder der udtrykkes ved grammatiske størrelser (idet afgrænsningen hovedsagelig er traditionelt bestemt, jf. Boye \& Harder 2012). Et eksempel er kategorien tempus, som opstilles når grammatiske morfemer såsom affikser eller hjælpeverber markerer forskelle mellem om et udsagn omhandler nutiden eller fortiden.

Hvad det grammatiske angår, er det teoretiske grundlag imidlertid udtømt med konstateringen af at der foreligger en kodning ved noget man traditionelt opfatter som grammatiske morfemer. Resten af beskrivelsen drejer sig om rent semantiske forhold. Tværsproglige kategorier er derfor typisk defineret alene ud fra betydningsområder, som fx når man definerer tempus som omhandlende ydre tidsmæssig forankring, mens aspekt omhandler intern tidsmæssig konfiguration (jf. Comrie 1976: 5).

Artiklens første tese er at denne diskussion med fordel kan afklares med henvisning til (en funktionelt baseret, opdateret version af) sondringen mellem struktur og substans (jf. Engberg-Pedersen et al. 1996; Harder 2016).

Problemstillingen er behandlet teoretisk af Haspelmath (2010) i en indflydelsesrig artikel. Hans nøglebegreb er "comparative concepts", her oversat til "komparative kategorier". En komparativ kategori er en tværsproglig kategori som er opstillet med henblik på at etablere en sammenlignende redegørelse for kategorier i en række enkeltsprog. Det kan være på generisk niveau som i eksemplet tempus, eller det kan være et bestemt valg inden for den generiske kategori, såsom præteritum. Ifølge Haspelmaths teori må sådanne tværsproglige kategorier forstås alene som subjektive stipulationer - noget lingvisten selv kan opstille som hun vil.

Vores næste tese er at denne fremstilling er ufuldstændig: Det er rigtigt at det som udgangspunkt er op til lingvisten at opstille sådanne tværsproglige kategorier - de springer ikke direkte ud af virkeligheden som den foreligger for beskriveren. Men som alle andre videnskabelige begreber kan de underkastes en validering, dvs. en procedure hvor man undersøger om de begreber lingvisten foreslår opstillet, lever op til de kriterier man har for 
holdbare teoretiske begreber. Fx viste begrebet "flogiston" sig ikke at være et holdbart begreb i fysikken.

Videre argumenterer vi for at semantiske kort ("semantic maps") kan bruges til at validere en bestemt type af komparative kategorier, nemlig generiske semantiske kategorier a la aspekt og tempus. Artiklen giver en gennemgang af hvordan en sådan valideringsprocedure kan se ud.

I fortsættelse heraf diskuterer vi implikationerne af denne procedure for den tværsproglige kategori aspekt, således som den fremstår i Comries indflydelsesrige fremstilling (Comrie 1976). Vi argumenterer for - som artiklens sidste hovedtese - at aspekt-kategorien ikke kan bestå en sådan valideringstest (på basis af data fra Bybee et al. 1994), og søger at vise hvorfor den ikke kan det.

\section{Substans og struktur i typologisk perspektiv}

Fra sprogvidenskabens barndom har man opereret med sproglige kategorier på tværs af sprogene. Som beskrevet ovenfor er tværsproglige kategorier baseret på ligheder mellem sprog med hensyn til hvilke betydningsområder der udtrykkes ved grammatiske størrelser. Således er kategorien tempus defineret ud fra at grammatiske morfemer i sproget markerer forskelle mellem om et udsagn omhandler fx nutiden eller fortiden. Hvordan denne lighed nærmere skal karakteriseres, forholder traditionen sig ikke til. Det er derfor også meget forskelligt hvad der i forskellige grammatikker og forskellige sprog opfattes som tempus, fx om det inkluderer (præsens) perfektum og pluskvamperfektum (= præteritum perfektum), futurum og konditionalis. Dette problem er fra traditionen overtaget i analyser på forskellige teoretiske præmisser, inklusive europæisk strukturalisme, generativ grammatik og moderne kognitiv og funktionel grammatik

Et grundproblem er spørgsmålet om præcis hvad forholdet er mellem de betydningsområder der er basis for intuitionen om bestemte tværsproglige kategorier, og de teoretiske grundlag der skal levere kriterierne for at opstille kategorier. De mest indflydelsesrige teorier i tiden giver forskellige svar på dette spørgsmål. Groft sagt opererer formalistiske teorier med en ret klar adskillelse mellem semantiske og grammatiske kategorier, mens funktionalistiske teorier antager en ret direkte sammenhæng mellem semantiske og grammatiske kategorier.

Vi argumenterer for at en opdateret forståelse af dansk tradition, som den er kommet til udtryk i dansk funktionel lingvistik, kan levere et nyttigt svar på spørgsmålet. Dansk funktionel lingvistik afviger fra såvel formalisti- 
ske tilgange som andre funktionalistiske tilgange ved at søge at opstille en sammenhængende teori der omfatter både den nødvendige forskel og den nødvendige sammenhæng imellem semantiske og grammatiske kategorier. Denne teori beror på den klassiske strukturalistiske sondring mellem form og substans (jf. Saussure 1916, Hjelmslev 1943) i en opdateret version (jf. Engberg-Pedersen et al. 1996; Boye 2012: 7; Harder 2016). Det afgørende i denne opdatering er at substans omtolkes fra at være det mindre vigtige - det som lingvisten skal lægge bag sig - til at være den nødvendige ramme omkring al lingvistisk teoridannelse. En lingvistisk teori som ikke er integreret med en fremstilling af den substantielle basis, savner således den nødvendige ontologiske forankring.

Saussure anfører som et leksikalsk mønstereksempel på at sproglig betydning er løsrevet fra det der betegnes, at man i engelsk sondrer mellem sheep og mutton, mens man på fransk kun har én betegnelse, nemlig mouton. Det rigtige i ræsonnementet er at man ikke kan aflede sproglige betydninger direkte fra verdens indretning - men dette begrunder ikke den strukturalistiske dogmatik ifølge hvilken det lingvistisk relevante alene er ordenes placering i et netværk af modsætninger ("valeur" med Saussures betegnelse). Forholdet er i stedet at betydningsområdet er en nødvendig baggrund, uden hvilken de sproglige modsætninger bliver uforståelige: Hvis ikke man tager udgangspunkt i en forståelse af hvad 'får' er for noget (både i Frankrig og England), kan man ikke forklare hvad forskellen mellem sprogene egentlig er - man kan kun sige at man på engelsk har "ord 1" og “ord 2", mens man på fransk kun har "ord 3". Man kan beskrive dette som et generelt træk ved figur-grund-fænomener: Man kan ikke behandle figuren uden at have grunden med i teorien.

Det er derfor nødvendigt at have en eksplicit teori der også inkluderer semantisk substans som forudsætning for at opstille og afgrænse sproglige struktureringer. Netop i forbindelse med typologiske kategorier er dette vigtigt - fordi sprogstrukturer som udgangspunkt vedrører sprogspecifikke forhold. Kategorier på tværs af sprogene må ifølge denne betragtning som udgangspunkt være baseret på semantisk substans, altså på fællesmængder af det betegnede på tværs af sprogene. Dette er i fuld overensstemmelse med den antagelse som blev beskrevet ovenfor som den man intuitivt tog for givet i traditionen: Vi observerer at to sprog har udtryk for noget vi som udgangspunkt opfatter som "det samme" - i det leksikalske eksempel 'făr', i det grammatiske eksempel tidsreference - og denne (substans)lighed er så grundlag for teoridannelsen om tværsproglige kategorier.

En metodologisk forudsætning for denne teori er dermed at man rent 
faktisk kan beskrive hvori denne semantiske substans består, uafhængigt af det sprogtegn man benævner den ved. Dette afspejler den funktionalistiske grundtanke at sprog får betydning ved at indgå (= "fungere") i en sammenhæng som foreligger uafhængigt af sproget selv. Uden adgang til en sådan forståelse kan man ikke diskutere hvilke betydningsstørrelser der i det enkelte sprog udhæves som strukturelt relevante, og hvordan disse adskiller sig fra hinanden fra sprog til sprog.

Fra et funktionelt-kognitivt synspunkt må semantisk substans forstås ikke direkte som størrelser i den fysiske verden, men som potentielt meddelelsesindhold hos sprogbrugere. Substans er således knyttet til muligheden for at meddele sig - men ikke til en bestemt sproglig indkodning. Struktur er derimod (til forskel fra substans) kendetegnet ved kun at kunne beskrives som egenskaber ved den måde betydninger er indkodet i et bestemt sprog.

Valget af et bestemt sprogtegn forudsætter og indebærer en strukturering af den substans man vil lade indgå i sin meddelelse - en engelsktalende vælger således ved brugen af mutton en bestemt semantisk figurering af betydningssubstansområdet 'făr' - nemlig at anskue det som noget der er beregnet til at spise. Tilsvarende vælger man ved at udtrykke sig i præteritum, fx i udsagnet verden var af lave, at anskue indholdet som en fortidig situation, hvor man ved valget af præsens (verden er af lave) ville have udtrykt det som en egenskab ved den aktuelle situation. Disse valg er i situationen overladt til sprogbrugeren - men de eksisterer kun for sprogbrugeren fordi de på forhånd er fastlagt som en del af de sproglige konventioner der foreligger i det pågældende sprogsystem.

I modsætning hertil er substanskategorier ikke begrænset af hvad det enkelte sprog udskærer af potentielle betydningsdomæner. Tid foreligger fx som noget man kan have til hensigt at udtrykke sig om, uanset hvilket sprog man vælger at udtrykke sig i. Der gælder imidlertid en motiverende relation mellem substanskategorier og strukturelle kategorier: Substansområder som sprogbrugere ofte har lyst til at indkode, er gode kandidater til at have en strukturel plads i sprogene. Også i sådanne tilfælde er det imidlertid metodologisk vigtigt at skelne mellem substanskategorien og strukturkategorien - ellers ville man netop ikke meningsfuldt kunne tale om at substanskategorien motiverer at der foreligger en strukturel modsvarighed.

Det følger af denne beskrivelse at substanskategorier er potentielt universelle. Når man ikke kan hævde uden forbehold at substanskategorier er universelle, er det fordi man ikke kan tage for givet at alle sprogsamfund opererer med samme potentielle meddelelsesindhold. Tid er et af de berømte diskussionsemner her; og doktrinen om at man må have styr på 
substansen, betyder her at man er nødt til at forstå hvad sprogbrugere siger til hinanden, før man kan sige noget meningsfuldt om det strukturelle - det kan fx godt tænkes at man har et begreb om tid uden at dette er strukturelt privilegeret i ens sprogsystem.

Sammenligning af strukturelle kategorier på tværs af sprog forudsætter således at man antager at sprogbrugere, på tværs af sprog, i et vist omfang deler semantisk substans. Hvis man antog at hver kultur levede i fuldstændig forskellige betydningsverdener, ville dette ikke være muligt. Man må derfor også lægge til grund at der findes - som en del af den virkelighed sprogene indgår i - et fænomen man kan kalde "tværsprogligt fælles betydningssubstans". Heri ligger som nævnt ikke at al betydning er fælles på tværs af sprogene - kun at noget af det er, og det er dette som kan indgå i typologiske sammenligninger. I modsat fald ville sprogsammenligning være umulig. Det er denne fælles sproglige betydningssubstans som udgør det "tertium comparationis" som typologi må bygge på.

På denne baggrund kan Haspelmaths (2010) "komparative kategorier" det mest indflydelsesrige bud på grundlaget for typologisk teori - nærmere beskrives som (formodede) substansregioner - dvs. kandidater til at udgøre delområder af den tværsproglige fællesmængde af betydningssubstans inden for hvilken typologisk sammenligning er mulig. Som beskrevet i indledningen er et afgørende træk ved komparative kategorier som anskuet af Haspelmath at de ikke udgør empiriske fund, men er noget der stipuleres af lingvisten. Det betyder at de er "konstrukter" (Haspelmath 2010: 666), at de ikke kan være rigtige eller forkerte (Haspelmath 2010: 678), og at de kun kan være "mere eller mindre produktive", dvs. at de tillader formuleringen af mere eller mindre interessante underinddelinger og generaliseringer (Haspelmath 2010: 678). Ifølge denne tanke er der ikke blot ingen garanti for at komparative kategorier beskriver sammenhængende substansdomæner - det er overhovedet ikke muligt at validere (eller forkaste) dem.

Disse beskrivelser er efter vores opfattelse ikke forkerte inden for de rammer Haspelmath selv har fastlagt. Forskellen er at vi tillægger muligheden for at validere komparative kategorier en afgørende rolle i teorien, mens Haspelmath netop ser bort fra muligheden af en sådan validering. Hvis man indsætter en valideringsprocedure som en nødvendig del af teorien, gælder Haspelmaths forbehold kun hvad der er tilfældet forud for at valideringen er gennemført. Indtil da er det således rigtigt at kategorier er noget lingvisten er frit stillet til at opstille.

For at give et eksempel kunne man som et tankeeksperiment opstille to typer verber der udtrykker 'total' hhv. 'partiel ændring', med mulige eksem- 
pler på total ændring så som dø/drebe, smuldre/knuse og mulige eksempler på partiel ændring som forfalde/skade, forbedre(s). Derefter kunne man så se om der kom noget interessant frem på tværs af sprogene. Vi ville på forhånd tro at dette ikke ville vise sig at være specielt produktivt - men der er ikke noget der hindrer en lingvist $i$ at opstille disse kategorier.

Vi finder at det giver bedst teoretisk mening hvis man går ud fra følgende præmisser: 1) For at komparative kategorier kan gøre fordring på at have status af teoretiske begreber, skal de ledsages af en validering/dokumentation af hvilke tværsproglige ligheder de kan bruges til at subsumere; 2) i så fald er de ikke længere frit opfundne produkter af lingvistens fantasi; 3) i stedet må forskellen i status mellem validerede og ikke-validerede komparative kategorier ses som videnskabsteoretisk analog med forskellen mellem en arbejdshypotese og en begrundet konklusion om beskaffenheden af den semantiske substans der er fælles for sprogene.

\section{Validering af generiske semantiske komparative kategorier}

Denne opfattelse vil nu blive illustreret i relation til en bestemt type af tværsproglige størrelser der er central i typologisk lingvistik (især for en funktionel betragtning). Her tænkes på tværsproglige deskriptive kategorier som aspekt, evidentialitet og numerus, som (når alle de centrale egenskaber skal med) kan beskrives som generiske, semantiske og komparative.

Disse kategorier er semantiske $\mathrm{i}$ den forstand at de dækker betydningsområder (snarere end morfosyntaktiske eller fonologiske ligheder). De er generiske $\mathrm{i}$ den forstand at de dækker områder der kan underinddeles $\mathrm{i}$ mere specifikke værdier: Aspekt dækker således perfektiv og imperfektiv, inklusive habituel og progressiv aspekt (jf. Whorf 1956 om "generic" vs. "specific categories'). De er komparative i den forstand at de bruges som udgangspunkt for at beskrive hvilke strukturelle kategorier der indgår i specifikke sprogsystemer - men de betegner altså ikke en egenskab der er defineret ved at høre hjemme i et eller flere specifikke sprog. For nemheds skyld nøjes vi herefter ofte med at tale om "generiske komparative kategorier".

Sådanne generiske komparative kategorier beskrives i Bybee, Perkins og Pagliuca (1994) som "clusters of grams" - fx "aspect", "evidentials", "epistemic moods" (Bybee et al.1994: 316-324). Bybee et al.s syn på disse kategorier svarer til Haspelmaths: Komparative kategorier er stipulationer. Ifølge Bybee et al. er de (1) bare bekvemme "meaning labels" (pp. 316-324); 
(2) "not structurally significant categories" (p. 3); (3) men de repræsenterer dog "cognitively significant semantic domains" (p. 3).

I modsætning til både Haspelmath og Bybee et al. mener vi at generiske kategorier bør ses som arbejdshypoteser om signifikante sproglige substansområder, ikke kun som vilkårlige stipulationer. Det betyder ikke at de i sig selv nødvendigvis er 'kognitivt virkelige' som enheder der kan påvises i (alle) sprogbrugeres kognitive repræsentation af verden. Deres eksistensmodus ligger $i$ at de udgør "steder hvor det sner" i den menneskelige erfaringsverden når man skal beskrive hvor sprogene "kaster deres skygge", dvs. lægger strukturelle distinktioner ned over substansen. Men først og fremmest er de dele af den betydningsverden som man empirisk kan konstatere at sprog er fælles om at indkode.

Vi skal nu se nærmere på hvordan man kan validere en generisk komparativ kategori, dvs. bekræfte en hypotese om at den fælles semantiske substans omfatter underkategorier så som tempus, numerus og aspekt. En sådan påvisning indebærer at det pågældende semantiske substansområde er signifikant for beskrivelsen af sprogspecifikke strukturelle træk i konkrete sprog.

Der kan opstilles i hvert fald følgende måder at validere generiske substanskategorier på: validering på basis af konceptuelt sammenhængende distributionelle systemer, validering på basis af skopus-egenskaber og validering baseret på semantiske kort, jf. Boye (2012). I det følgende beskriver vi hvordan man kan gennemføre en validering baseret på semantiske kort.

Grundlaget for opstillingen af semantiske kort kan beskrives som følger: Semantiske kort afbilder relationer mellem formodede semantiske substansværdier (= semantiske komparative kategorier) ved at placere dem på et fælles semantisk territorium (heraf betegnelsen "kort"). Semantiske kort udnytter videre det faktum at sprogspecifikke udtryk slår semantiske substansværdier sammen på forskellige måder på tværs af sprogene; disse forskellige "sammenslåninger" kan så bruges til at beskrive forholdet mellem de involverede semantiske størrelser. Kriteriet for at identificere en substansrelation - og afbilde den som en forbindelseslinje - mellem to komparative kategorier på et semantisk kort er at der findes udtryk som 1) er polyfunktionelle og dækker begge kategorier, eller 2) har flyttet sig diakront fra den ene til den anden kategori. Tilfældig homonymi eller portmanteau-fænomener gælder ikke da de ikke manifesterer semantisk sammenfald (jf. Croft 2001; Haspelmath 2003).

Et eksempel på et semantisk kort er kortet over epistemisk betydning i figur 1 (jf. Boye 2010, 2012). Kortet er fremkommet ved at definere en række 
semantiske komparative kategorier og identificere relationer mellem dem på grundlag af ovenfor nævnte kriterium. Det fremgår af figur 1 at der er belæg for relationer fx mellem kategorierne 'direkte informationskilde' og 'fuld støtte' og kategorierne 'medium støtte' og 'minimal støtte'. Kategorierne på kortet er som sagt substanskategorier, og relationerne mellem dem er lingvistisk signifikante substansrelationer. Det følger heraf at kortet giver et indtryk af konturer i den semantiske substans.

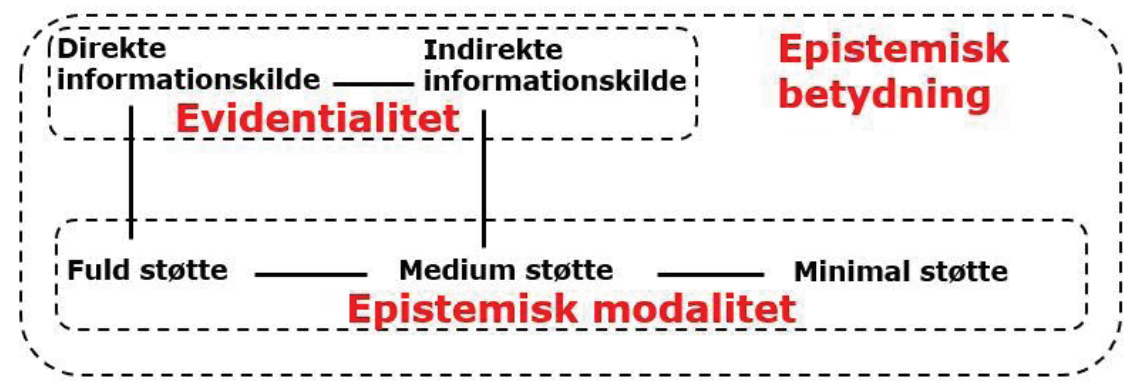

Figur 1: Semantisk kort over epistemisk betydning (efter Boye 2010, 2012).

Figur 1 kan også tjene til at illustrere hvordan semantiske kort kan udnyttes i valideringen af generiske semantiske komparative kategorier som lingvistisk signifikante substansbeskrivelser. Som kriterium for sådan validering foreslår vi følgende:

\section{Kriterium for validering af generiske semantiske kompa- rative kategorier:}

En semantisk komparativ kategori må dække et sammenhængende område på et semantisk kort. Med andre ord må hver eneste af de specifikke kategorier der dækkes af den generiske komparative kategori der valideres, være relateret til mindst en af de andre specifikke kategorier der dækkes af den generiske kategori (Boye 2010, 2012).

Med dette kriterium kan evidentialitet og epistemisk modalitet valideres som generiske komparative kategorier vha. kortet i figur 1. På kortet er de specifikke kategorier der omfattes af disse generiske kategorier (for evidentialitets vedkommende 'direkte' og 'indirekte informationskilde'; for epistemisk modalitets vedkommende 'fuld', 'medium' og 'minimal støtte') direkte forbundet med mindst en anden specifik kategori. Både evidentialitet og epistemisk modalitet dækker altså sammenhængende områder på 
kortet i figur 1. Det samme gør overkategorien epistemisk betydning eller "epistemicitet".

I næste afsnit skal vi undersøge om det samme kan siges om en anden af de veletablerede semantiske betydningskategorier: aspekt.

\section{Kan aspekt valideres som generisk komparativ kategori?}

Vi lægger her den klassiske behandling i Comrie (1976) til grund for vores diskussion af aspekt. Ifølge Comrie (1976: 5) handler aspekt om den interne temporale beskaffenhed af den indkodede situation. Ud fra de samme principper som er anvendt på epistemisk betydning, kan man tentativt udlede et substansområde der omfatter Comries aspekt-underkategorier, og undersøge om Comries aspekt kan valideres som generisk komparativ kategori.

Vores undersøgelse bygger på datasættet fra Bybee et al. (1994), som består af 315 verbalmorfemer fra 76 sprog. Til sammenligning kan vi henvise til van der Auwera \& Plungians (1998) kort over modalitet, der ligeledes er baseret på Bybee et al. (1994). Datasættet indeholder fire forskellige kategorier som er en del af Comries aspekt-beskrivelse: perfektiv, imperfektiv, progressiv og habitualis. Derudover har vi også inkluderet kategorier som ofte relateres til aspekt: tempuskategorier (præteritum, præsens, futurum), resultativ og anterior (førtid). Disse ikke-aspektuelle kategorier er taget med i undersøgelsen fordi vi forventer at de vil være tæt forbundne med aspektkategorierne. Der er ikke nogen risici ved at inkludere flere kategorier i undersøgelsen, for hvis de viser sig ikke at være relevante for undersøgelsen, vil de simpelthen ikke være forbundne med nogen andre kategorier på kortet. På et klassisk semantisk kort vil der kun være forbindelser mellem kategorier hvor der er empirisk belæg for det. Det er også vigtigt at pointere at vi har gjort brug af Bybee et al.s data som de har kodet og kategoriseret dem. Det vil sige at vi har brugt deres kategorier som de har defineret dem. Deres aspektkategorier er dog baseret på Comries definitioner (Bybee et al. 1994: 125) og egner sig derfor godt til at undersøge Comries aspekt begreb empirisk.

Det semantiske kort over aspektuelle og relaterede kategorier ses i figur 2. 


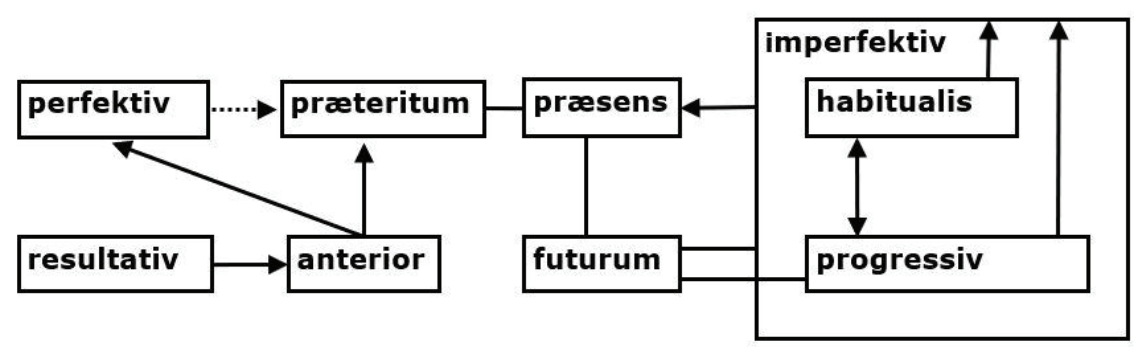

Figur 2: Semantisk kort over aspektuelle og relaterede kategorier.

Det semantiske kort skal læses sådan at hver firkant repræsenterer en specifik komparativ kategori. Der er altså ni specifikke komparative kategorier på kortet. Linjerne viser synkront attesterede forbindelser mellem kategorierne, og pilene viser diakront attesterede forbindelser (jf. afsnit 3). Fx repræsenterer pilen mellem anterior og perfektiv en tendens til at morfemer som udtrykker anterior, udvikler sig til perfektiver over tid. Boksen til højre repræsenterer det forhold at imperfektiv er overbegreb til habitualis og progressiv. Pilene fra habitualis og progressiv til den store imperfektiv-boks afspejler at morfemer som udtrykker habitualis eller progressiv, ofte udvikler sig til imperfektiver. Den stiplede pil mellem perfektiv og præteritum afspejler at datagrundlaget for forbindelsen mellem disse to specifikke kategorier er usikkert.

I det følgende gennemgår vi to eksempler på forbindelser på kortet, og hvordan de er underbygget af data.

1) Forbindelsen mellem futurum og progressiv er underbygget af to morfemer i datasættet. Baluchi (indoiransk, Pakistan) har et morfem, əga bu, der udtrykker progressiv og forventet fremtid (Bybee et al. 1994: 276), og pangasinansk (austronesisk, Filippinerne) har et morfem, on, der udtrykker futurum og progressiv (via reduplikation) (Bybee et al. 1994: 277), jf. figur 3.

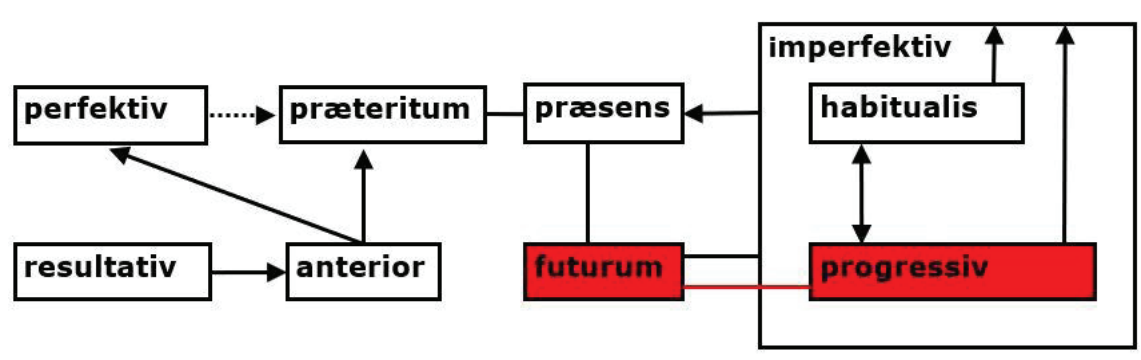

Figur 3: Forbindelse mellem futurum og progressiv. 
2) Forbindelsen mellem progressiv og imperfektiv understøttes af at progressiver ofte udvikler sig til imperfektiver ved at udvide deres betydningsområde til at indbefatte habituel. Dette er dokumenteret fx i yoruba (niger-congo, Nigeria) (Bybee et al. 1994: 141), jf. figur 4.

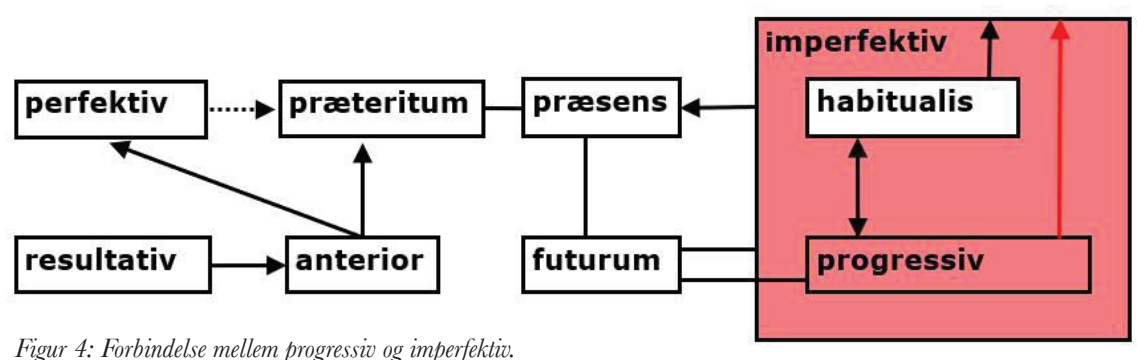

Figur 4: Forbindelse mellem progressiv og imperfektiv.

På baggrund af kortet i figur 2 og det kriterium for validering af generiske semantiske komparative kategorier der blev opstillet i afsnit 3 , kan vi nu undersøge om aspekt (i Comries forstand) kan valideres som generisk komparativ kategori. Som det fremgår af kortet, udgør aspekt i modsætning til epistemisk betydning ikke et internt sammenhængende område på kortet. Aspekt omfatter pr. Comries definition perfektiv og imperfektiv (og herunder progressiv og habitualis). På kortet er disse specifikke aspektuelle kategorier opdelt i to grupper, perfektiv til venstre side og imperfektiv med underkategorier til højre, og man kan ikke på kortet relatere perfektiv til imperfektiv uden at gå uden for aspekt-området, nemlig via tempusbetydninger. Det betyder at aspekt ikke dækker et sammenhængende substansområde. Dermed kan kategorien ikke valideres ifølge den opstillede valideringsprocedure. I modsætning hertil kan tempus valideres, for så vidt som det defineres som omfattende præteritum, præsens og futurum. Disse tre specifikke kategorier udgør et sammenhængende område på kortet, jf. figur 5 .

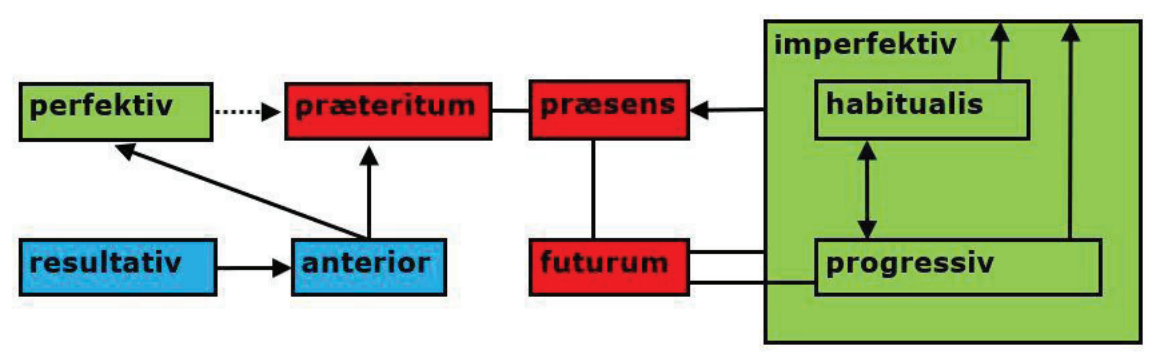

Figur 5: Semantisk kort over aspektuelle og relaterede kategorier med fremharning af de aspektuelle (gronne) og temporale (rode) kategorier. 


\section{Aspekt som en strukturelt funderet kategori}

Afvisningen af aspekt som generisk komparativ kategori rejser spørgsmålet om aspekt-begrebet som helhed er fejlagtigt konstrueret, a la flogiston?

Det mener vi ikke det er. Problemet er et andet, nemlig at aspekt ikke har samme ontologiske fundering i en tværsprogligt fælles betydningssubstans som tempus, skønt det er hvad man plejer at antage. I stedet har det en anden fundering der er lige så interessant for typologisk teori, om end den kan siges ikke at være fundamental på samme måde: Aspekt er baseret på en strukturel distinktion mellem to betydningsområder - ikke på et semantisk substansområde som sådan. Distinktioner antages normalt at høre under struktur, ikke under substans - eller, sagt på en anden måde, distinktioner er ikke en del af det semantiske grundstof: En distinktion forudsætter at der på forhånd foreligger noget substans, og en distinktion er så noget man lægger ned over denne substans. I forhold til kort-metaforen er en distinktion ikke et område, men en granse: Det der er på den ene side af grænsen, har én status, og det der er på den anden side af grænsen, en anden.

Aspekt kan altså ikke forstås som dækkende et sammenhængende substansdomæne, men som et overbegreb for en tværsprogligt genkommende distinktion. Denne forståelse er faktisk i overensstemmelse med Comries, for så vidt som han definerer aspekt som et overbegreb for en række binære modsætninger; se figur 6.

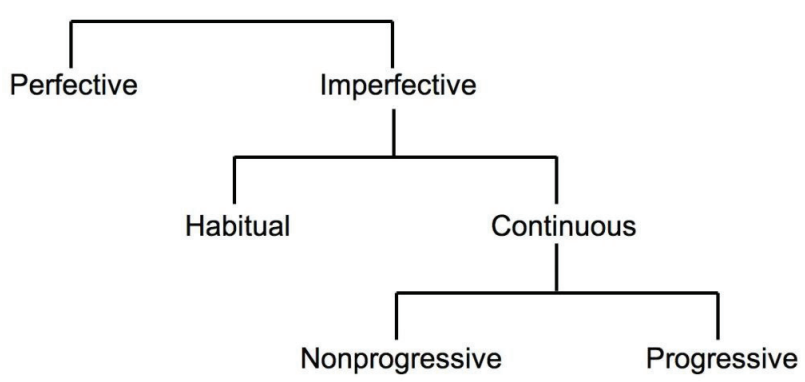

Figur 6: Comries klassifikation af aspektkategorier (Comrie 1976: 25).

Fordi Comries aspektforståelse bygger på modsætninger, er der ingen garanti for at den er forenelig med en substansbaseret indholdsbeskrivelse. Dette viser sig også ved konfrontation med de typologiske data (jf. Bybee et al. 1994: 139): Udtryk for "non-progressiv" kan ikke påvises, og udtryk for "continuous" kan heller ikke påvises. Derfor anvender Bybee et al. (1994) 
også kun termen "imperfektiv" om udtryk der dækker både habituel og progressiv.

Distinktioner udelukker naturligvis ikke substanskontinuitet som sådan, men der kan argumenteres for at binære distinktioner gør: Hvor forskellige underområder som futurum og progressiv kan vises at være relateret til hinanden fordi der findes morfemer der dækker begge betydningsområder, er det af gode grunde utænkeligt at et morfem havde en betydning der både dækkede perfektiv og imperfektiv (så ville hele den aspektuelle faktor være neutraliseret væk).

Fra en empirisk synsvinkel er det dog ikke nødvendigt at opfatte aspekt som dækkende en binær distinktion. Imperfektiv kan opløses i de kategorier det omfatter, progressiv og habitualis, således at der identificeres tre specifikke aspektkategorier: perfektiv, progressiv og habitiualis, som illustreret i figur 7 .

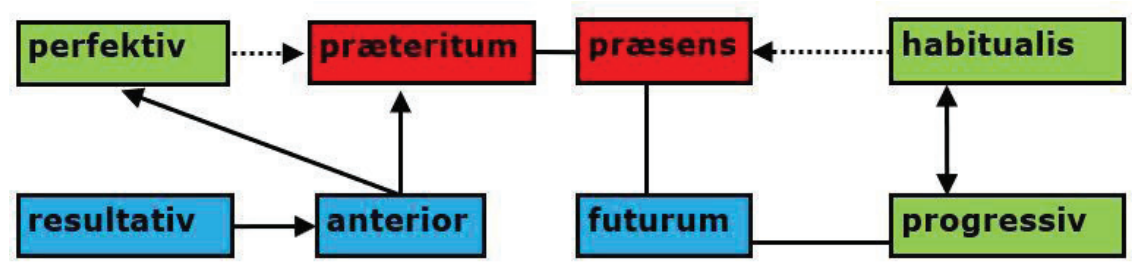

Figur 7: Semantisk kort over aspektuelle og relaterede kategorier uden imperfektiv.

Der er intet problematisk i en sådan opløsning. Der er ikke mere grundlag for at opstille den komparative kategori imperfektiv end der ville være for at opstille en kategori for udtryk der dækker både perfektiv og præteritum. Progressiv og habituel betydning dækkes ofte af samme udtryk - men det gælder også perfektiv og præteritum. At bruge termen imperfektiv som om den udtrykte et semantisk område der subsumerede både habituel og progressiv, vil være "squinting grammar": Det har kun mening fordi man ved at der i andre sprog er en binær modsætning til perfektiv.

Selv ikke hvis imperfektiv fjernes fra det semantiske kort, og man således beskriver aspekt som en non-binær kategori, kan kategorien imidlertid valideres som generisk komparativ kategori: Der er ingen direkte forbindelse på det semantiske kort i figur 7 mellem perfektiv på den ene side og progressiv eller habitualis på den anden, og dermed dækker aspekt ikke et sammenhængende område af kortet. 


\section{Sammenfatning}

Vi har argumenteret for følgende fire hovedteser:

1. Den teoretiske fundering af begrebet "komparative kategorier" må forstås på basis af en antagelse om at der eksisterer en fællesmængde af potentielt indkodelige betydningsområder på tværs af nogle eller alle sprog. Denne fællesmængde består af hvad vi med baggrund i dansk strukturalistisk tradition kalder indholds- eller betydningssubstans, forstået som det der er genstand for strukturering (opskæring, "cutting the pie") i enkeltsprogene. Komparative kategorier er navne på formodede funktionelt-kognitive substansområder (regioner) der udgør delområder i det samlede fælles territorium af tværsprogligt attesterede betydningsområder.

2. Komparative kategorier opstår som subjektive stipulationer (jf. Haspelmath 2010), men hvis de er testet - og bestået - på deres egnethed til at profilere strukturelle ligheder og forskelle mellem sprog, går de fra at være rene arbejdshypoteser til at være underbyggede teorier (om det tværsproglige semantiske substansområde). Generiske komparative kategorier er således hypoteser om tværsprogligt signifikante substansområder. De kan valideres ved at det påvises at de udgør betydningsområder der gør det muligt at sammenligne strukturelle distinktioner på tværs af sprogene.

3. Semantiske kort er beskrivelser af substansområder baseret på undersøgelser af et antal sprogspecifikke strukturer (samkodning, udskæring af betydningsområder) og kan som sådan bruges til at validere generiske komparative kategorier. Sådanne kategorier er validerede hvis de dækker sammenhængende områder af semantiske kort.

4. Comries aspekt-kategori kan ikke valideres som tværsproglig substanskategori, baseret på Bybee et al.s (1994) data. I stedet udgør den en anden, ontologisk afvigende type af generalisering: en generalisering baseret på tværsprogligt genkommende strukturelle distinktioner.

\section{Om forfatterne}

Kasper Boye, lektor i lingvistik, Institut for Nordiske Studier og Sprogvidenskab, Københavns Universitet.

Jessie Leigh Nielsen, ph.d.-stipendiat, Institut for Nordiske Studier og Sprogvidenskab, Københavns Universitet. 
Peter Harder, professor i engelsk, Institut for Engelsk, Germansk og Romansk, Københavns Universitet.

\section{Litteratur}

Boye, K. (2010): Semantic maps and the identification of cross-linguistic generic categories: Evidentiality and its relation to epistemic modality. Linguistic Discovery 8(1), 4-22.

Boye, K. (2012): Epistemic meaning: A crosslinguistic and functional-cognitive study. Berlin: Mouton de Gruyter.

Bybee, J., Perkins, R. \& Pagliuca, W. (1994): The evolution of grammar: Tense, aspect, and modality in the languages of the world. Chicago: The University of Chicago Press.

Comrie, B. (1976): Aspect: An introduction to the study of verbal aspect and related problems. Cambridge: Cambridge University Press.

Croft, W. (2001): Radical Construction Grammar: Syntactic theory in typological perspective. Oxford: Oxford University Press.

Engberg-Pedersen E., Fortescue M., Harder, P., Jakobsen, L.F., Heltoft L. (red.) (1996): Content, Expression and Structure. Studies in Danish Functional Grammar. Amsterdam: John Benjamins.

Harder, P. (1996): Functional semantics. Berlin: Mouton de Gruyter.

Harder, P. (2016): Substance(s) and the rise and imposition of structure(s). Acta Linguistica Hafniensia 48(1), 7-34.

Haspelmath, M. (2003): The geometry of grammatical meaning: Semantic maps and crosslinguistic comparison. I: The new psychology of language: Cognitive and functional approaches to language structure 2. Tomasello, M. (red.). London: Lawrence Erlbaum, 211-242.

Haspelmath, M. (2010): Comparative concepts and descriptive categories in crosslinguistic studies. Language 86(3), 663-687.

Saussure, F. de. (1916) [2005]: Cours de linguistique générale. Paris: Payot.

Van der Auwera, J. \& Plungian, V. A. (1998): Modality's semantic map. Linguistic Typology 2(1), 79-124.

Whorf, B. L. (1956) [1940]; Science and linguistics. I: Language, thought, and reality: Selected writings of Benjamin Lee Whorf. Carroll, J.B. (red.). Chicago: MIT Press, 207-219. 